\section{Predicting Fate of the Contraceptive Pill in Wastewater Treatment and Discharge}

M. Mastrup ${ }^{*}$, A. I. Schäfer ${ }^{* *}$, S.J. Khan ${ }^{* *}$

Ingeniørhøjskolen Odense Teknikum, Niels Bohrs Alle 1, 5230 Odense M, Denmark. Environmental Engineering, University of Wollongong, NSW 2522, Australia.

(Email: Schaefer@uow.edu.au).

\section{Abstract}

The risk of endocrine disrupters to humans and wildlife is to date poorly understood, although evidence of effects is now widespread. In understanding the risk, an important step is the determination of the partitioning, as well as chemical and biochemical transformation, of compounds in the environment, the water cycle and the food chain. This is a complex task and this paper is a first step towards estimating some of these factors from a largely theoretical approach. A chemical fate model is used to predict the fate of the contraceptive drug $17 \alpha$-ethinylestradiol (EE2). The example of the contraceptive pill is chosen to follow the journey of the drug from human ingestion and excretion to treatment in a sewage treatment plant (STP) using into the estury/sea. The model predicts how EE2 will partition into the different compartments during each stage of this journey and thereby infiltrate into the food chain. The results suggest that a person would have to ingest more than 30,000 portions of fish to consume an equivalent to a single average dose of the contraceptive pill. While this scenario is highly unlikely, the biochemical consequence of the contraceptive pill is greatly significant. Furthermore, there are many identified similarly estrogenic compounds in the environment while this study only considers one. Cumulative effects of such compounds as well as degradation into other potent compounds may be anticipated. An important message in this paper is the interrelation of wastewater effluent discharge and eventual human exposure of marginally degradable and lipophilic chemicals. While at present the main concerns regarding endocrine disrupters appear to be the fear of their occurrence in drinking water sources, it is clear that the domains of wastewater treatment and discharge, water suggests that exposure from food (contaminated by effluent) may be much more significant than from drinking water.

Keywords:

Endocrine disrupting chemicals, fugacity modelling, wastewater treatment.

\section{INTRODUCTION}

A major facilitator of the freedom of women in the last forty years was the development of the contraceptive pill. Scientists found that it was not possible to use the natural hormones, such as $17 \beta$-estradiol for contraceptive purposes as these are not sufficiently lipophilic to be significantly absorbed from the digestive tract. Thus, a series of drugs that would have the same effect as the naturally occurring hormones, but which would have a higher bioavailability in the body, were subsequently synthesized. A satisfactory synthetic derivative of $17 \beta$-estradiol was found in $17 \alpha-$ ethinylestradiol (EE2). This was, however, just one of many. Today the two major contraceptives used are EE2 and mestranol, which is the methyl ester of EE2. The chemical structures of those estrogens are shown in Figure 1. While these enhaced contraception, they may well have contributed to new problems of environmental and possibly health consequences. One desired characteristic of the drugs was increased persistence in the human body. This has the inevitable consequence of persistence in the environment. As a consequence of incomplete absorption of these compounds in the human body, a significant proportion of the prescribed compounds are excreted in active or inactive forms.

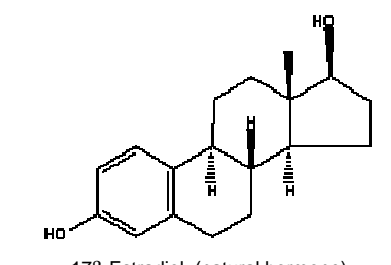

17ק-Estradiol (natural hormone)
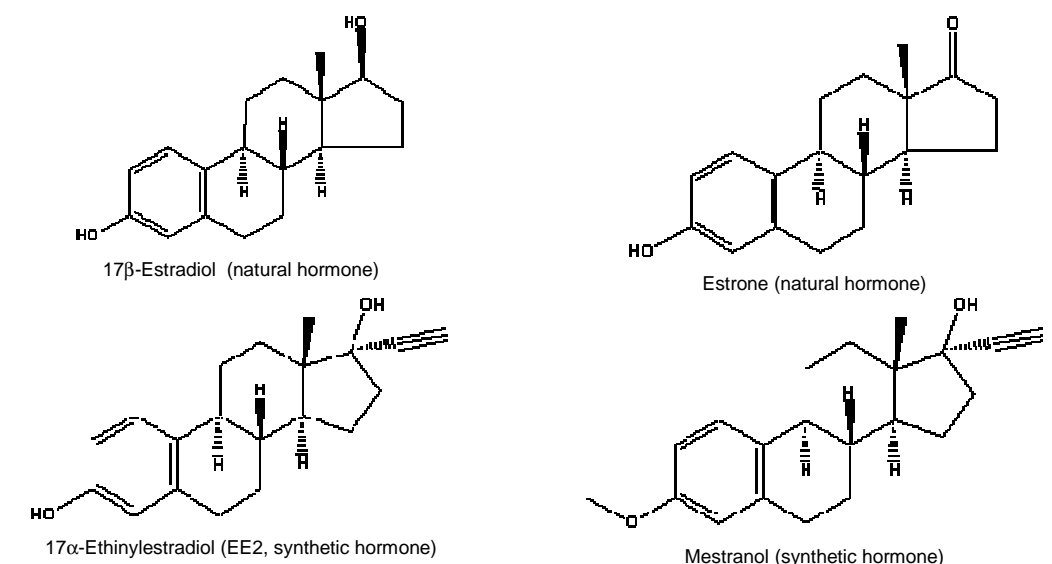

Figure 1 Natural and synthetic estrogenic steroidal hormones of interest.

As early as 1973 analytical methods were developed to quantify the amount of natural and synthetic hormones in sewage treatment plants (STPs) (Kirchner et al. 1973). In 1977 drinking water wells and springs in Germany and in 1979 drinking and river water in the Netherlands were analysed for EE2, which was indeed detected in the lower nanogram per litre range (Rurainski et al. 1977, Rathner et al. 1979). Since then there have been many reported findings of the drug in STP effluents, in rivers and even in drinking water (Aherne et al. 1989, Desbrow et al. 1996, Belfroid et al. 1999 and Ternes et al. 1999a). While most findings in surface waters are in the lower nanogram per litre range, some report concentrations up to several hundred $\mu \mathrm{g} / \mathrm{L}$ (Stumpf et al. 1996; Tabak et al. 1981; Ternes et al. 1999a; Jurgens et al. 1999; Snyder et al., 1999; Solé et al., 2000; Ying et al., 2002).

Since it has been confirmed that contraceptive drugs have become abundant in the aquatic environment, possible environmental consequences demand a need to understand their fate and removal mechanisms. To do this effectively it is necessary to understand how the drug partitions into the different compartments of our environment. For example, partitioning of the hormones onto natural particles may cause a removal of the drugs from natural waters with an accumulation in the sediments. Adsorption to microorganisms may facilitate uptake and subsequent degradation.

One way of understanding the fate of a molecule is by taking samples from different environmental compartments for analysis. This method is not only very time consuming, but also extremely costly as in many cases, the analytical techniques are not readily available. This is particularly the case when compounds are sorbed onto solids.

A useful facilitator is to develop a model that can be used to generate useful predictions to help understand the fate of the contaminants. A number of models have been developed to cover a wide range of chemicals, each limited assumptions with varying degrees of applicability.

In this paper a fugacity-based approach has been used to model the chemical fate of EE2. Fugacity has been described as the escaping tendency of a chemical substance from a phase and is therefore measured in units of pressure (Pa) (Mackay et al. 1981, Hemond and Fechner-Levy 2000). Fugacity models account for partitioning and degradation of a chemical in a phase to predict steady-state concentrations.

In this study, two different models were applied, one for the STP (Clark et al.1995) and one for the environment (Mackay et al. 1981 - Level 2). The models use the physical-chemical properties of the chemicals to predict the fate of the compounds. Chemical concentration is given 
by the product of the fugacity $(f)(\mathrm{Pa})$ and the fugacity capacity of the specific environmental compartment $(\mathrm{Z})\left(\mathrm{mol} / \mathrm{m}^{3} \mathrm{~Pa}\right)$. Since there are three different compartments or mediums in the simplified STP there are three fugacity capacities to be calculated, one each for air, water and biomass. These are calculated as follows:

Air

$$
Z_{\text {Air }}=\frac{1}{R \cdot T}
$$

Water

$$
\mathrm{Z}_{\mathrm{w}}=\frac{1}{\mathrm{H}}
$$

Biomass

$$
Z_{B}=0.2 \cdot K_{\text {OW }} \cdot Z_{W}+0.8 \cdot Z_{W}
$$

Where $\mathrm{R}$ is the ideal gas constant $\left(8.324 \mathrm{Pam}^{3} / \mathrm{mol} \mathrm{K}\right), \mathrm{T}$ is the absolute temperature $(\mathrm{K}), \mathrm{H}$ is Henry's Law constant for the chemical $\left(\mathrm{Pam}^{3} / \mathrm{mol}\right)$ and $\mathrm{K}_{\mathrm{Ow}}$ is the octanol-water partitioning coefficient for the chemical.

Table 1 Chemical characteristics of EE2(Lai et al. (2000), pKa calculated using Pallas 3.0 Software).

\begin{tabular}{cccccc}
\hline $\begin{array}{c}\text { Molecular } \\
\text { weight }\end{array}$ & Log Kow & $\begin{array}{c}\text { Solubility in } \\
\text { water }\end{array}$ & $\mathrm{H}$ & pKa & $\begin{array}{c}\text { Vapour } \\
\text { pressure }\end{array}$ \\
\hline$(\mathrm{g} / \mathrm{mol})$ & $(-)$ & $(\mathrm{mg} / \mathrm{L} \mathrm{at} \mathrm{20})$ & $\left(\mathrm{Pa}-\mathrm{m}^{3} / \mathrm{mol}\right)$ & $(-)$ & $(\mathrm{mm} \mathrm{Hg})$ \\
\hline 296.4 & $3.67-4.15$ & 4.8 & $7.9410^{-12}$ & 10.61 & $4.510^{-11}$ \\
\hline
\end{tabular}
$9410^{-12}$

tank, the For the STP, the fugacity of the contaminants in the primary sedim neveloped by Clark et al. (1995). The equations are reproduced below.

$$
\begin{aligned}
& \text { Primary sedimentation tank } \quad \mathrm{f}_{\mathrm{p}}=\frac{\mathrm{E}}{\left(\mathrm{D}_{2}+\mathrm{D}_{3}+\mathrm{D}_{\mathrm{PV}}+\mathrm{D}_{\mathrm{PB}}\right)} \\
& \text { Aeration tank } \\
& \mathrm{f}_{\mathrm{A}}=\frac{\mathrm{D}_{2} \mathrm{f}_{\mathrm{P}}}{\left[\mathrm{D}_{5}+\mathrm{D}_{6}+\mathrm{D}_{\mathrm{AB}}-\left(\frac{\mathrm{D}_{8} \mathrm{D}_{6}}{\mathrm{D}_{7}+\mathrm{D}_{8}+\mathrm{D}_{9}+\mathrm{D}_{\mathrm{SV}}+\mathrm{D}_{\mathrm{SB}}}\right)\right]} \\
& \mathrm{f}_{\mathrm{S}}=\frac{\mathrm{D}_{6} \mathrm{f}_{\mathrm{A}}}{\mathrm{D}_{7}+\mathrm{D}_{8}+\mathrm{D}_{9}+\mathrm{D}_{\mathrm{SV}}+\mathrm{D}_{\mathrm{SB}}} \\
& \text { Settling tank }
\end{aligned}
$$

The subscripted numbers relate to the streams shown in Figure 2. While the subscript $\mathrm{P}$ stands for the primary sedimentation tank, A for aeration tank and $\mathrm{S}$ for the settling tank. The subscripted $\mathrm{V}$ is for volatilisation and $\mathrm{B}$ for biodegradation. The inflow of the chemical in question is denoted with an $\mathrm{E}$, and has units of $\mathrm{mol} / \mathrm{h}$.

The D values $(\mathrm{mol} / \mathrm{Pah})$ are fugacity rate parameters for transportation and degradation in various streams and compartments of the model STP, and can be calculated from the following relationships.

$$
\begin{array}{lll}
\text { Streams } & D=G \cdot Z \\
\text { Degradation } & D=V \cdot Z \cdot k
\end{array}
$$

here $\mathrm{G}$ is the flow of either air, water or biomass in $\mathrm{m}^{3} / \mathrm{h}, \mathrm{V}$ is the volume of the respective phase in $\mathrm{m}^{3}$ and $\mathrm{k}$ is a first-order rate constant in $\mathrm{h}^{-1}$.

Since EE2 is non-volatile the D values for vaporization have been set to zero, except for the aeration tank where the forced aeration might be of importance.

\section{SEWAGE TREATMENT PLANT (STP)}

For the STP calculations, a series of parameters have been used to simulate a standard secondary small STP, as shown in Table 2. The concentration of EE2 in raw sewage has been modelled at 1 $\mathrm{ng} / \mathrm{L}$ which is roughly consistent with several reported studies.

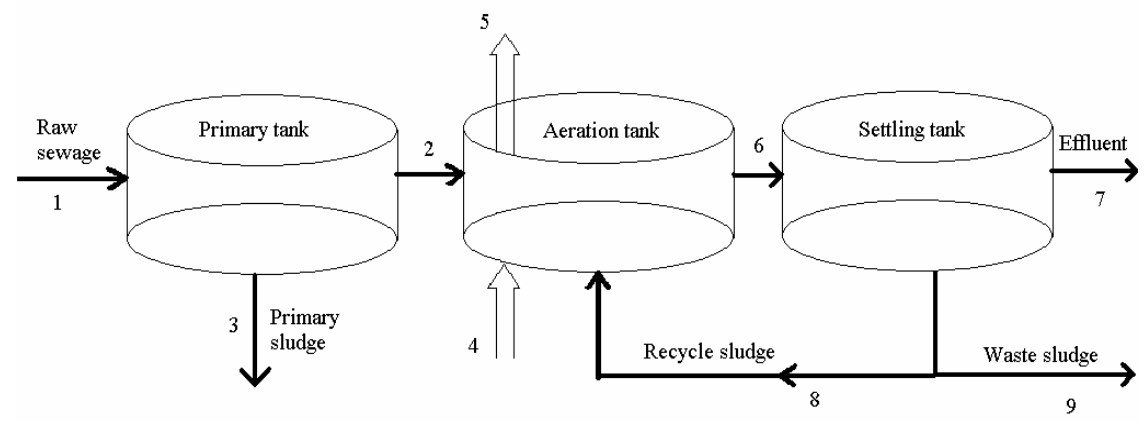

Figure 2 Diagram of the simplified secondary sewage treatment plant (STP) used in this model.

There are many reported removal rates of EE2 in sewage ranging from almost complete to negligible. The precise situation will rely heavily on the biomass present and the design and operation of the specific STP. The assignment of aerobic biodegradation rates to chemicals during activated sludge treatment processes is a notoriously difficult and highly imprecise task (Khan and Ongerth, 2004). Ternes et al. (1999b) observed that EE2 is largely stable under aerobic conditions in an activated sludge process. To roughly simulate this observation, the appropriate half-lives in this model have been selected as 200 hours.

The model predicts a concentration of EE2 in the primary sludge of $38.5 \mathrm{ng} / \mathrm{L}$ (see Table 3), which reflects the strong partitioning of this compound to biomass. The lower concentration predicted in the secondary waste sludge is attributed to biodegradation. The predicted effluent concentration of $0.75 \mathrm{ng} / \mathrm{L}$ is comparable to some of the lower values actually found in effluents and indicates that only $25 \%$ of the contaminant was removed. About $10 \%$ of the chemical was predicted to be removed via biodegradation. Given this predicted effluent concentration it was then possible to further predict how this chemical would partition in the environment when discharged into a receiving water. No further consideration was given to the fate of the contaminant in the solids phases.

Table 2 Parameters for the STP that have been used for the model.

\begin{tabular}{lcr}
\hline \multicolumn{1}{c}{ Parameter } & $\mathrm{Unit}$ & \multicolumn{1}{c}{ Value } \\
\hline Person equivalent & - & 180 \\
Influent rate & $\mathrm{m}^{3} / \mathrm{h}$ & 1000 \\
Contaminant inflow concentration & $\mathrm{ng} / \mathrm{L}$ & 1.0 \\
MLSS (Mixed liquor suspended solids) & $\mathrm{g} / \mathrm{m}^{3}$ & 2500 \\
Solid inflow & $\mathrm{g} / \mathrm{m}^{3}$ & 200 \\
Solid outflow & $\mathrm{g} / \mathrm{m}^{3}$ & 15 \\
Primary tank overflow & $\mathrm{m}^{3} / \mathrm{m}^{2}$ day & 90 \\
Settling tank overflow & $\mathrm{m}^{3} / \mathrm{m}^{2}$ day & 33 \\
Depth of vessels & $\mathrm{m}$ & 3.80 \\
Primary sludge concentration & $\mathrm{g} / \mathrm{m}^{3}$ & 50000 \\
Recycle sludge fraction & - & 0.80 \\
Air flow as a percentage of aeration tank volume & $\%$ & 112 \\
\hline
\end{tabular}

Air flow as a percentage of aeration tank volume

112

Table 3 Outlet concentrations from the STP in ng/L. Sludge concentrations are typically given in term of $\mathrm{mg} / \mathrm{kg}$ and can be calculated by dividing concentration below by sludge density.

\begin{tabular}{lccc}
\hline Outlets [ng/L] & Primary sludge & $\begin{array}{c}\text { Waste secondary } \\
\text { sludge }\end{array}$ & Effluent \\
\hline $17 \alpha-$-ethinglestradiol & 38.5 & 4.5 & 0.8
\end{tabular}

17a-ethinylestradiol

38.5

4.5 
Mastrup, M. ; Schäfer, A. I. ; Khan, S. (2005) Predicting fate of the contraceptive pill in wastewater treatment and discharge, Water Science \& Technology, 52, 8, 279-286.

Table 4 Contaminant degradation rates in the STP.

\begin{tabular}{lc}
\hline STP compartment & Degradation rates $[\mathrm{ng} / \mathrm{h}]$ \\
\hline Primary tank & 2760 \\
Aeration tank & 95500 \\
Settling tank & 5270
\end{tabular}

Table 5 Chemical fate in the STP as percent of contaminant in the effluent, sludge and degradation.

\begin{tabular}{lc}
\hline & Chemical fate [\%] \\
\hline Primary sludge & 6.6 \\
Waste secondary sludge & 6.8 \\
Effluent & 73 \\
Biodegradation: Primary tank & 0.3 \\
& 9.5 \\
& Aeration tank \\
Settling tank & 0.5 \\
\hline
\end{tabular}

\section{THE ENVIRONMENT}

To predict the chemical fate of EE2 once it has been discharged into the environment from the STP, it was necessary to define a model environment. For this it was assumed that the effluent was being released into a river, which flows into the ocean about $3 \mathrm{~km}$ downstream. The river was divided into three equally long parts and the estuary was also taken into account to provide a total of four discrete compartments. The dimensions of the four compartments have been selected to simulate a typical river and estuary, while depth of sediment, amount of suspended solids and the volume fraction of fish used are those that have been previously recommended in literature (Mackay et al. 1997, Jurgens et al., 1999). Figure 3 shows the model structure and Table 7 gives the parameters that have been used in the environment model. As can be seen from Table 8 , most of the EE2 $(60 \%)$ is predicted to stay in the water phase and gradually dilute. The water concentration in the river is approximately $0.01 \mathrm{ng} / \mathrm{L}$ and in the estuary approximately $0.0003 \mathrm{ng} / \mathrm{L}$. The difference is predominantly due to dilution. The river concentration is notable since experiments with rainbow trout have revealed that an observable feminisation effect from oestrogenic hormones down to a concentration of $0.1 \mathrm{ng} / \mathrm{L}$ (Desbrow et al.1996). This order of magnitude may well be achieved if several estrogenic substances and their cumulative effects are accounted for. Such feminisation effects have been reported on many occasions in waters receiving effluent.

$$
\text { STP : Seawage treatment plant }
$$

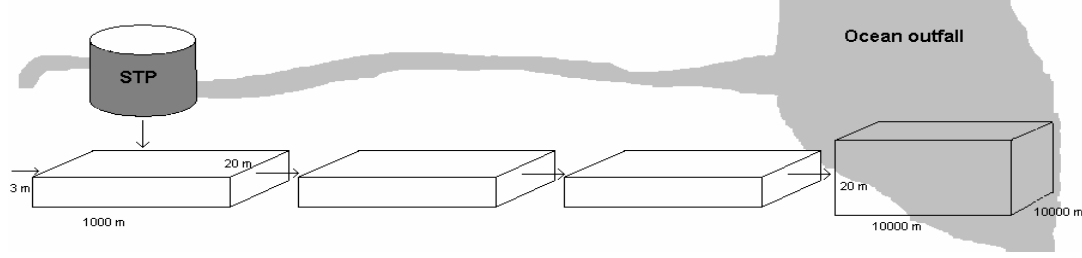

Figure 3 Model structure of the defined model environment.
Table 6 Parameters for the simulations.

\begin{tabular}{|c|c|c|}
\hline & River & Estuary \\
\hline \multicolumn{3}{|l|}{ Water Column } \\
\hline Depth (m) & 3 & 20 \\
\hline Width (m) & 20 & 10000 \\
\hline Length $(m)$ & 1000 & 10000 \\
\hline Resident time $(\mathrm{h})$ & 1 & 1000 \\
\hline Sediment & & \\
\hline Depth $(m)$ & 0.01 & 0.01 \\
\hline $\begin{array}{l}\text { Suspended Sediment } \\
\text { Amount }\left(\mathrm{g} / \mathrm{m}^{3}\right) \\
\text { Fish }\end{array}$ & 20 & 10 \\
\hline $\begin{array}{l}\text { Fish } \\
\text { Amount (\%) }\end{array}$ & $1 \cdot 10^{-4}$ & $110^{-4}$ \\
\hline
\end{tabular}

The model predicted that EE2 would partition strongly into the bed sediment to almost $40 \%$. Again this can be attributed to the high $\mathrm{K}_{\mathrm{OW}}$ value. The concentration of EE2 was predicted to be highest in the suspended sediment, owing to the high organic content of the sediment assumed in the model. Of particular note, however, is the predicted bioconcentration of the hormone in fish, -almost $3 \mathrm{ng} / \mathrm{L}$ or $3 \mathrm{ng} / \mathrm{kg}$ assuming a fish density of $1 \mathrm{~kg} / \mathrm{L}$ (Hemond \& Fechner-Levy, 2000, p56). The degradation rate in the river is very small, and only about $1 \%$ of the EE2 was predicted to be degraded over the distance of $3 \mathrm{~km}$. This is due to the high flow rate in the river, which makes advection the major removal mechanism, and a relatively low microbiological activity. However, upon approaching the ocean, about $25 \%$ of the remaining EE2 was predicted to be degraded within the 1000 hours that was estimated to be the average residence time in an estuary. This was not caused by a lower half-life, but by a lower flow rate, and therefore longer residence time. Figure 4 shows how degradation of EE2 is dependant on the river flow rate.

To put these results into context, the amount of fish that a person would need to consume to achieve a dose comparable to the contraceptive pill has been estimated. A fish weight of $200 \mathrm{~g}$ per portion has been assumed. A single portion was calculated to contain 0.6ng of EE2. An average contraceptive pill contains $20 \mu \mathrm{g}$ EE2 (Goodman \& Gilman, 1996). Thus for a similar dose, a person would have to eat about 30,000 portions (or $6000 \mathrm{~kg}$ ) of fish.

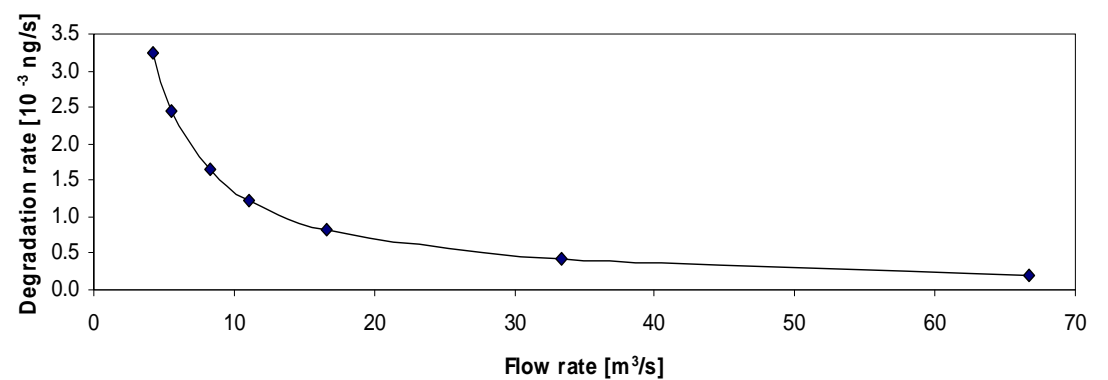

Figure 4 Degradation rate of EE2 in the river as a function of river flow.

Table 7 The partitioning of 17a-ethinylestradiol into different environmental compartments.

\begin{tabular}{l|cccc|cccc}
\hline & \multicolumn{3}{|c|}{ Concentration (ng/L) } & \multicolumn{4}{c}{ Chemical Fate (\%) } \\
\hline Scenario & Water & Sediment & $\begin{array}{c}\text { Suspended } \\
\text { sediment }\end{array}$ & Fish & Water & Sediment & Suspended & Fish \\
sediment & \\
River 1 & $1.3 \cdot 10^{-2}$ & 2.3 & 7.3 & 3.0 & 62 & 38 & 0.5 & 0.01 \\
River 2 & $1.310^{-2}$ & 2.3 & 7.3 & 3.0 & & & & \\
\hline
\end{tabular}




\begin{tabular}{l|cccc|cccc}
\hline River 3 & $1.3 \cdot 10^{-2}$ & 2.3 & 7.3 & 3.0 & & & \\
Estuary & $2.8 \cdot 10^{-4}$ & $5.2 \cdot 10^{-2}$ & 0.2 & $6.610^{-2}$ & 91 & 8.4 & 0.4 & 0.02 \\
\hline
\end{tabular}

For comparison of intake from food and water, the potential uptake from drinking water was also estimated. The equivalent dose of the contraceptive pill would be obtained by the consumption estimated. The equivalent dose of the contraceptive pill would be obtained by the consumption
of $1.5 \mathrm{ML}$ of surface water (assuming no further removal of EE2 during drinking water treatment of $1.5 \mathrm{ML}$ of surface water (assuming no further removal of EE2 during drinking water treatment
processes). With a daily water intake per person of $2 \mathrm{~L}$, this is about 750,000 "daily portions". processes). With a daily water intake per person of $2 \mathrm{~L}$, this is about 750,000 "daily portions".
While those numbers are clearly meaningless without knowing the health effects from exposure to low concentrations and the extent of cumulative effects, it is a useful estimation to predict that the exposure of EE2 from a single portion of fish might be significantly greater than that from the daily portion of drinking water.

\section{CONCLUSION}

Fugacity-based fate models can be used to predict the environmental fate of EE2 and many other trace contaminants. The model is useful to roughly predict steady-state concentrations in discrete environmental compartments. This tool has considerable potential particularly for those trace organic compounds for which analytical difficulties or expenses limit others forms of data collection. While the model has predicted very low concentrations of EE2 in fish and drinking water sources with an input concentration of $1 \mathrm{ng} / \mathrm{L}$, other authors have detected estrogen concentrations in the aquatic environment of up to $1 \mu \mathrm{g} / \mathrm{L}$ (Jurgens et al. 1999).

Future improvement and optimisation of the model may be achieved by improved understanding Future improvement and optimisation of the model may be achieved by improved understanding
of both chemical and environmental parameters. Biodegradation rates are a major source of of both chemical and environmental parameters. Biodegradation rates are a major source of
limitation and normally serve as illustrative examples only. A useful exception, to some degree, are compounds such as EE2 which have been observed to have such low rates of degradation that biodegradation can be considered to be only very minor over short periods of time. Improved understanding of rates and mechanism of adsorption of chemicals to solids will also lead to better modelling. Currently, the model relies on Kow values which are useful only in predicting lipophilic adsorption. Non-lipophilic mechanisms such as dipole interactions or ion-exchange the integration of specific interaction and sorption as a function of solution chemistry and sediment or particle characteristics as determined by Lai et al. (2000).

ACKNOWLEDGEMENTS The authors would like to thank Ingenioer Jens Jespersens Fond and IDA's Laane- og Hjaelpefond for Reinholdt W. Jorck og Hustrus Fond for providing a grant to Maibritt Mastrup.

\section{BIBLIOGRAPHY}

Aherne G.W. and Briggs R.J. (1989) "The relevance of the presence of certain synthetic steroids in the aquatic environment" J. Pharm. Pharmacol, 41, 735-736

Belfroid A.C., Van der Horst A., Vethaak A.S., Schäfer A.I., Rijs G.B.J., Wegener J. and Cofino W.P. (1999) "Analysis and occurrence of estrogenic hormones and their glucuronides in surface water and waste water in The Netherlands." Science of the Total Environment, 225 , 101-108

Clark B., Henry J.G., Mackay D. (1995) "Fugacity Analysis and Model of Organic Chemical Fate in a Sewage Treatment Plant" Environmental Science \& Technology, 29, 1488-1493
Desbrow C, Routledge E., Sheenan D., Waldock M. and Sumpter J. (1996) "The identification and assessment of oestrogenic substances in sewage treatment works effluents. MAFF Fisheries Laboratory and Brunel University: research and development project report P2 i490/7 published by the Environment Agency, Bristol, UK

Goodman Gilman A, Hardman J.G., Limbird L.E. (1996) “ Goodman \& Gilman's The Pharmacological Basis of Therapeutics. $-9^{\text {th }}$ edition, McGraw-Hill, USA Hemond H.F, Fechner-Levy E.J. (2000) "Chemical Fate and Transport in the Environment" $2^{\text {nd }}$ Edition, Academic Press

Jurgens M.D., Johnson A.C., Williams R.J. (1999) "Fate and Behaviour of Steroid Oestrogens in Rivers: A Scoping Study" R\&D Technical Report P161, Environment Agency, Bristol, UK

Khan, S. J. and Ongerth, J. E. (2004) Modelling of prescription pharmaceutical residues in Australian sewage based on quantities of use and fugacity calculations. Chemosphere, 54(3), 355-367.

Kirchner M., Holsen H. and Norpoth K.(1973) "Fluorescence Spectroscopic Determination of Anti-Ovulatory Steroids in Water and Waste Water on the Thin Layer Chromotography Plate" Zbl. Bakt. Hyg., I. Abt. Orig. B 157, 44-52

Lai K.M., Johnson K.L., Scrimshaw M.D., Lester J.N. (2000) "Binding of waterborne steroid estrogens to soilid phases in river and estuarine systems" Environmental Science \& Technology, 34, 3890-3894

Mackay D., Paterson S. (1981) “Calculating Fugacity” Environmental Science \& Technology, 15, 1006-1014

Mackay D., Shiu W., Ma K (1997) "Illustrated Handbook of Physical-Chemical Properties and Environmental Fate for Organic Chemicals" Volume 5, Lewis Publishers, USA

Rathner M., Sonnenborn P.A. (1979) "Biologisch wirksame Oestrogene in Trink- und Abwasser" Forum Stadte-Hygiene 30/3 45-49

Rurainsky R.D., Theiss H.D., Zimmermann W. (1977) "Über das Vorkommen von natürlichen und synthetischen Oestrogenen im Trinkwasser” gwf-wasser/abwasser. 118, 288-291

Snyder S. A., Keith, T. L. Verbrugge D. A., Snyder E. M., Gross T. S., Kannan K. and Giesy J. P. (1999). "Analytical Methods for Detection of Selected Estrogenic Compounds in Aqueous Mixtures." Environmental Science \& Technology 33: 2814-2820.

Solé M., Alda M. J. L. d., Castillo M., Porte C., Ladegaard-Pedersen K. and Barceló D. (2000) "Estrogenicity Determination in Sewage Treatment Plants and Surface Waters from the Catalonian Area (NE Spain).” Environmental Science \& Technology 34 (24): 5076 - 5083.

Stumpf M., Ternes T.A.m Haberer K., Baumann W. (1996) "Nachweis von natürlichen und Stumpf M., Ternes T.A.m Haberer K., Baumann W. (1996) "Nachweis von natürlichen
synthetischen Oestrogenen in Kläranlagen und Fliessgewässern" Vom Wasser 87 251-261

synthetischen Oestrogenen in Kläranlagen und Fliessgewässern" Vom Wasser 87 251-261
Tabak H.H., Bloomhuff R.N., Bunch R.L. (1981) "Steroid hormones as water pollutants II. abak H.H., Bloomhuff R.N., Bunch R.L. (1981) "Steroid hormones as water pollutants II.
Studies on the persistence and stability of natural urinary and synthetic ovulation-inhibiting hormones in untreated treated waste-waters" Developments in Industrial Microbiology 22497. 519

Ternes T.A., Stumpf M.,Mueller J., Haberer K., Wilken R.-D. and Servos M. (1999) "Behaviour and occurrence of estrogens in municipal sewage treatment plants - I. Investigations in Germany, Canada and Brazil" The Science of the Total Environment 225 81-90

Ternes T.A., Kreckel P. and Mueller J. (1999) "Behaviour and occurrence of estrogens in municipal sewage treatment plants - II. Aerobic batch experiments with activated sludge." The Science of the Total Environment 225 91-99

Ying G.-G., Williams B. and Kookana R. (2002). "Environmental fate of alkylphenols and alkylphenol ethoxylates- a review." Environment International 28(3): 215-226 